\title{
Pemanfaatan Budidaya Lele dan Maggot sebagai Pengembangan Alternatif Bisnis Industri Rumahan dan Pengolahan Limbah Rumah Tangga di Desa Sukowati Kecamatan Kapas Kabupaten Bojonegoro
}

\author{
Novianita Sari*1, Santi Retna Sari², Alfina Damayanti ${ }^{3}$ \\ 1,2,3Akuntansi, Prodi Akuntansi, Sekolah Tinggi Ilmu Ekonomi Cendekia Bojonegoro, Indonesia \\ *e-mail: novianitasari971@gmail.com ${ }^{1}$
}

\begin{abstract}
Abstrak
Peranan tenaga kerja yang terampil dan berpendidikan sangat berpengaruh dalam pertumbuhan ekonomi. Tetapi pada kenyataannya di Indonesia sendiri masih kekurangan tenaga kerja yang terampil dan berpendidikan. Wawasan masyarakat yang kurang memadai dalam mengolah sumber daya alam sering ditemukan di masyarakat pedesaan. Salah satunya masalah tersebut dapat dijumpai di desa Sukowati Kabupaten Bojonegoro. Dari permasalahan diatas maka dilakukan program pengembangan pemberdayaan desa (P3D) untuk menambah pendapatan warga. Kegiatan yang dilakukan adalah perluasan kolam ikan lele dan kandang maggot, pengadaan bank sampah, pembuatan produk inovasi yakni nugget ikan lele, abon ikan lele dan kerupuk ikan lele serta pemberian edukasi dalam pemasarannya. Dengan program diatas saling berhubungan antara lain olahan ikan lele yang memiliki nilai jual yang lebih tinggi sebagai pengembangan alternatif bisnis industri rumahan. Budidaya maggot sebagai salah satu pakan alternatif untuk pakan lele. Sampah organik dari bank sampah bisa digunakan untuk pakan manggot dan bank sampah yang bisa menggurangi dampak sampah rumah tangga yang ada dilingkungan Desa Sukowati. Dari kegiatan tersebut diharapkan warga Desa Sukowati memiliki wawasan yang cukup untuk melakukan pengembangan alternatif bisnis industri rumahan.
\end{abstract}

Kata-kata kunci: Alternatif Bisnis Industri Rumahan, Budidaya Lele, Manggot, Pemberdayaan Desa

\begin{abstract}
The role of a skilled and educated workforce is very influential in economic growth. But in reality, Indonesia itself still lacks a skilled and educated workforce. Insufficient public insight in processing natural resources is often found in rural communities. One of these problems can be found in the village of Sukowati, Bojonegoro Regency. From the above problems, a village empowerment development program (P3D) was carried out to increase the income of residents. The activities carried out are the expansion of catfish ponds and maggot cages, procurement of waste banks, manufacture of innovative products namely catfish nuggets, catfish floss, and catfish crackers as well as providing education in marketing. The programs above are interconnected, including processed catfish which has a higher selling value as an alternative development of a home industry business. Maggot cultivation as an alternative feed for catfish feed. Organic waste from the waste bank can be used for maggot feed and the waste bank can reduce the impact of household waste in the Sukowati Village environment. From this activity, it is hoped that the residents of Sukowati Village have sufficient insight to develop alternative home-based industrial businesses.
\end{abstract}

Keywords: Alternative Home Industry Business, Catfish Cultivation, Maggot, Village Empowerment

\section{PENDAHULUAN}

Salah satu masalah jangka panjang yang dihadapi suatu negara adalah pertumbuhan ekonomi. Pertumbuhan ekonomi dapat didefinisikan sebagai perkembangan kegiatan dalam perekonomian yang menyebabkan barang dan jasa yang diproduksi akan bertambah (Sukirno, 2011). Beberapa faktor yang mempengaruhi pertumbuhan ekonomi antara lain tanah dan kekayaan alam lainnya, jumlah dan mutu dari penduduk dan tenaga kerja, barang-barang modal dan tingkat teknologi serta sistem sosial dan sikap masyarakat.

Di negara berkembang sendiri salah satu masalah jangka panjang yang dihadapi dalam pertumbuhan ekonomi adalah peranan tenaga kerja yang terampil dan berpendidikan. Tetapi pada kenyataannya di indonesia sendiri masih kekurangan tenaga kerja yang terampil dan 
berpendidikan. Wawasan masyarakat yang kurang memadai dalam mengolah sumber daya alam sering ditemukan di masyarakat pedesaan.

Salah satunya ada desa di kabupaten Bojonegoro yang memiliki jumlah penduduk yang lumayan besar adalah di desa Sukowati kecamatan Kapas Kabupaten Bojonegoro. Dengan jumlah penduduk yang cukup besar ini, warga desa setempat seharusnya bisa memanfaatkan Sumber Daya Alam yang ada di wilayah tersebut. Potensi Sumber Daya Alam yang ada di desa Sukowati ini meliputi : lahan yang luas, lokasi yang strategis, dan mudah dijangkau karena lokasinya masih berdekatan dengan kota Bojonegoro.

Salah satu potensi alam yang dapat dimanfaatkan yaitu lahan yang luas sebagai tempat budidaya ikan lele dan maggot. Budidaya lele ini sudah banyak dikenal dan dilakukan oleh kebanyakan orang karena potensi bisnisnya sangat tinggi dan perawatannya cukup mudah. Sedangkan, untuk budidaya magot ini sudah ada sejak lama namun masih awam dikalangan masyarakat. Maggot adalah sejenis belatung yang dihasilkan dari lalat black souldier. Maggot ini memiliki beberapa kelebihan yaitu mampu menguraikan sampah dan dapat dimanfaatkan sebagai pakan ternak. Salah satunya yaitu dapat digunakan sebagai pakan ikan lele.

Kegiatan diatas sudah pernah dilakukan dalam program PHP2D tetapi ada beberapa permasalahan yang terjadi di masyarakat setelah dilakukanya program tersebut yakni keterbatasan dana yang digunakan untuk membuat kandang maupun tambak, dan kurangnya akses pemasaran produk abon lele. Oleh karna itu dalam program P3D ini kami melakukan perluasan kolam ikan lele, perluasan kandang maggot, menambahkan produk inovasi baru dan pendampingan kegiatan pemasaran secara online maupun offline.

Dengan adanya peternakan maggot yang lebih besar dan banyak, bisa dibentuk lagi kegiatan berupa pengadaan bank sampah. Kegiatan bank sampah ini setiap warga menyetorkan sampah/limbah rumah tangga berupa buah dan sayur. Sampah buah dan sayur busuk nantinya akan digunakan untuk memberi makan maggot. Selain itu kami akan menambah produk olahan rumah tangga warga desa sukowati antara lain: abon lele, nugget ikan lele dan kerupuk ikan lele sehingga pendapatan dari warga desa Sukowati menjadi bertambah. Jadi dari semua program diatas akan saling berhubungan.

Dengan adanya pendampingan yang diberikan diharapkan dapat meningkatkan Sumber Daya Manusia (SDM) warga desa Sukowati untuk melakukan kegiatan budidaya tersebut. Selain itu, kegiatan budidaya ini diharapkan mampu memberikan feedback yang bagus untuk warga setempat dengan hasil yang maksimal sehingga budidaya tersebut mampu berkembang dengan besar dan membantu perekonomian warga desa Sukowati. Berikut ini adalah beberapa penelitian dan pengabdian yang relevan dengan program ini:

a. Suwandi, Sudargo dan Sukma Nur Ardini pada tahun 2017 melakukan program pengabdian masyarakat yang mempunyai judul "Upaya Peningkatan Penghasilan bagi Warga Anggota Kelompokposdaya Melalui Budidaya Ikan Lele Di Pekarangan Rumah" dan hasil dari program tersebut untuk mahasiswa mampu menumbuhkan rasa kepedulian, empati, serta kepekaan sosial untuk kondisi permasalahan di masyarakat. Sehingga, dapat membangun kesadaran dan perubahan perilaku dan sikap mahasiswa yang diwujudkan dalam upaya pemberdayaan masyarakat yang sesuai dengan bidang keilmuan dan kondisi yang sebenarnya.

b. Wiwin Widiasih, Siti Muhimatul Khoiroh, Handy Febri Satoto, Agung Prasetyo, Prastyo Eka Yunianto melakukan penelitian dan pengabdian pada tahun 2020 dengan judull " PKM Budidaya Lele Sebagai Alternatif Mata Pencaharian Petani Sawah Tadah Hujan Di Desa Jukong". Dari program tersebut diperoleh hasil bahwa yaitu pembuat kolam untuk budidaya ikan lele untuk meningkatkan produktivitas lele dilakukan sosialisasi mengenai hal tersebut. Selain itu untuk meningkatkan keterampilan dan kompetensi dalam mengelola budidaya dilakukan pelatihan manajemen keuangan dengan bentuk pembuatan pembukuan keuangan yang sederhana. Dengan melakukan kegiatan diatas bisa mengatasi dalah satu masalah dalam perekonomian yang dialami petani sawah tadah hujan di desa Jukong.

c. Budi Prasetyo melakukan penelitian pada tahun 2021. Yang memiliki judul" Efektivitas Penggunaan Maggot Segar (Hermetia Illucens) Pada Ransum Terhadap Pertumbuhan Ikan Lele (Clarias sp.)“ dari penelitian tersebut dapat disimpulkan bahwa penggunaan maggot sebagai pengganti tepung ikan pada pembuatan ransum tidak efektif terhadap pertumbuhan 
ikan lele. Tapi Maggot dapat dijadikan sebagai pengganti tepung ikan jika maggot segar dicampur dengan pakan komersil untuk menekan biaya produksi dan meningkatkan laju pertumbuhan ikan.

d. Buyung Purnomo Waluyo dan Jefri Putri Nugraha melakukan penelitian pada tahun 2020 dengan judul "Analisis Usaha Pembesaran Lele Dengan Menggunakan Pakan Tambahan Maggot Black Soldier Fly (Bsf) Di Upr Christanto Darmawan Yogyakarta Business Analysis Of Catfish Enlargement Using Black Soldier Fly (Bsf) Maggot As Additional Feed In Upr Christanto Darmawan Yogyakarta" dari penelitian tersebut didapatkan hasil bahwa Usaha pembesaran lele dengan jumlah tebar 6.000 ekor dengan volume ir $32 \mathrm{~m} 3$ dan diberi pakan tambahan maggot layak untuk dijalankan karena menghasilkan keuntungan sebesar Rp.4.177.500,- dan nilai R/C Ratio 1,72, serta dapat menghemat biaya untuk pengadaan pelet sebesar Rp. 1.808.000,- atau sebesar 29,72 \% jika dibandingkan dengan menggunakan 100\% pelet.

e. Salman, L.M. Ukhrowi, M.T. Azim pada tahun 2022 melakukan penelitian yang diberi judul "Budidaya Maggot Lalat BSF Sebagai Pakan Ternak". Dari penelitian tersebut di peroleh hasil bahwa Pengolahan sampah organik menjadi media tumbuh lalat BSF dalam usaha budidaya maggot lalat BSF memberi pengaruh yang positif. Selain menjaga kebersihan dan kesehatan lingkungan dari segi pemanfaatan sampah buangan berupa sampah organik, juga mendapat animo positif dari warga Desa Pendem. Nilai eknomis yang dihasilkan dari budidaya maggot lalat BSF ini adalah produksi pakan ternak khusus ternak unggas dan ikan yang memiliki nilai jual yang tinggi di pasaran. Selain itu juga dihasilkan pupuk organik sisa media tumbuh maggot lalat BSF.

f. Nico E.G. Mudeng, Jeffrie F. Mokolensang, Ockstan J. Kalesaran, Henneke Pangkey, Sartje Lantu melakukan penelitian pada tahun 2018 yang berjudul "Budidaya Maggot (Hermetia illuens) dengan menggunakan beberapa media (Cultvation of Maggot (Hermetia illuens) using several different media) ". Dala penelitian tersebut dapat ambil kesimpulan bahwa Media budidaya yang baik untuk produksi maggot (H. illucens) adalah dengan menggunakan media limbah rumah makan dengan produksi mencapai 182,7 g dengan lama waktu pemeliharaan 10 hari.

g. Fenny Fitriani, Ulaivia Imaniska, Ingga Lastari Faustiar dan Evitrianti Mudjihartik tahun 2019 melakukan penalitian dan pengabdian yang berjudul "Pelatihan Pengolahan Nugget Lele Bagi Masyarakat Desa Gelang Sidoarjo“. Dari kegiatan yang dilakukan diperoleh hasil bahwa hasil budidaya ikan lele yang dimiliki oleh warga berjalan dengan baik dan mendapatkan respon baik dari warga desa Gelang yang terdiri atas warga dusun Gelang dan warga dusun Karang Ploso. Selain itu juga meningkatkan konsumsi ikan lele oleh anak-anak dan bernilai jual.

\section{METODE}

Kegiatan ini tidak sepenuhnya dilakukan secara offline karena diberlakukannya PPKM pada saat masa pendemi, namun dalam pemantauan berkaitan dengan praktek langsung dilapangan dilakukan secara langsung tetap dengan menggunakan protokol kesehatan. Metode yang digunakan dalam kegiatan ini adalah :

a. Sosialisasi budidaya lele dan magot (DILEMA) yang dilakukan secara online via Zoom. Sosialisasi ini diikut oleh beberapa warga desa seperti anggota karang taruna desa sukowati dan juga ibu-ibu PKK desa sukowati.

b. Perluasan kolam ikan lele dan pemisahan lele berdasarkan dengan ukurannya. Kegiatan ini dilakukan bersama dengan beberapa warga desa Sukowati dan didampingi oleh tim kami.

c. Selanjutnya bersama beberapa warga desa akan melakukan pelebaran kandang maggot dan memisahkan antara maggot, pupa, dan lalat.

d. Pengadaan program bank sampah yang bertujuan untuk meningkatkan kebersihan lingkungan.

e. Pembuatan produk abon lele, nugget lele, dan kerupuk lele.

f. Lalu kemudian kami memberikan edukasi tentang bagaimana pemasaran produk yang baik sehingga bisa berkembang pada saat masa pandemi COVID-19. Pemasaran ini dilakukan melalui outlet-outlet yang lebih banyak dan media sosial juga marketplace yang lebih gencar. 
Kegiatan ini diperluas sampai kepada seluruh dusun di desa Sukowati, dengan cara promosi melalui kegiatan pertemuan rutin setiap bulan melalui musrembangdes tiap desa, kami juga bekerjasama dengan Dinas Perikanan terkait lele dan Dinas Koperasi terkait produk kami.

Kami selalu melakukan pemantauan dan evaluasi tekait perkembangan maggot dan lele yang ada di rumah-rumah warga sehingga tidak terjadi kematian massal dan terus berkembang menjadi produk olahan yang bisa menghasilkan uang. Kami juga aktif memberikan edukasi mengenai bagaimana cara berternak dan bertambak yang benar dan menghasilkan banyak maggot dan lele yang sehat.

\section{HASIL DAN PEMBAHASAN}

Setelah adanya program PHP2D masyarakat desa Sukowati menjadi lebih produktif karena ada yang berternak maggot, ada yang bertambak lele, dan sebagian besar ibu-ibu warga desa yang tergabung dalam PKK sudah melakukan pembuatan abon. Tetapi hanya untuk dikonsumsi pribadi tidak untuk dijual secara luas. Selain itu kolam ikan lele dan kandang maggot yang masih kecil. Serta kurangnya pengetahuan tentang pemasaran produk inovasi dari ikan lele tidak banyak memebantu perekonomian di masyarakat desa Sukowati.

Ada beberapa permasalahan yang terjadi di masyarakat setelah dilakukanya program tersebut yakni keterbatasan dana yang digunakan untuk membuat kandang maupun tambak, dan kurangnya akses pemsaran produk abon lele. Oleh karna itu untuk membantu mengatasi masalah diatas kami melakukan beberapa metode dalam progaram P3D ini.

\subsection{Sosialisasi Budidaya Lele dan Magot (DILEMA)}

Yang pertama kami melakukan sosialisi secara online via zoom. Dalam kegiatan tersebut dijelakan tentang rancangan program yang kami lakukan. Yakin perluasan kolam lele dan maggot yang telah ada di desa sukowati.

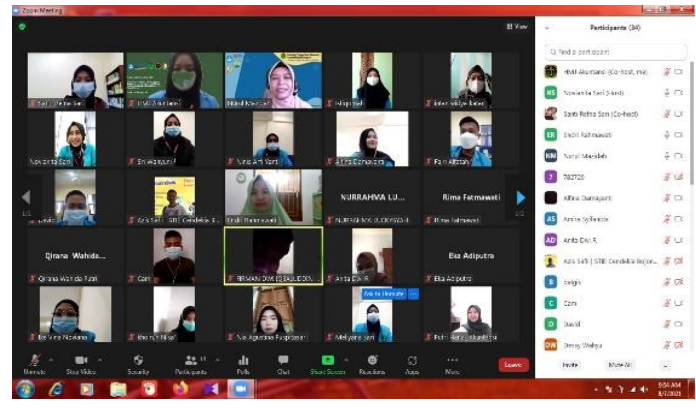

Gambar 1. Sosialisali perluasan kolam lele dan kandang manggot

Selain itu juga dijelaskan mengenai pengadaan bank sampah yang di gunakan sebagai pakan untuk maggot, menjaga kebersihan lingkungan. Selanjutnya kami juga menjelaskan bawah akan ada produk tambahan dari olahan ikan lele yaitu yang sebelumnya hanya berupa abon lele akan bertambah dengan nugget lele dan kerupuk lele.

\subsection{Perluasan Kolam Ikan Lele}

Kegiatan selanjutnya adalah perluasan kolam ikan lele. Perluasan ini dilakukan secara langsung oleh warga Sukowati dan diampingi oleh beberapa tim kami, dikarnakan kegiatan ini dilaksanakan dalam masa PPKM.

Hal pertama yang dilakukan adalah pengalian untuk perluasan kolam terpal. Dengn ukuran kolam yang sebelumnya hanya $2 \times 2$ meter sekarang di tambah dengan kolam yang lebih luas yakni dengan ukuran $2 \times 3$ meter. Selain memperluas kolan dari terpal kami juga menambahkan kolam yang berasal dari gentong. Disini kami memilih gentong karna beberapa alasan, seperti mudah dipindahkan dan tidak telalu banyak menggunakan lahan. Tidak memakan banyak waktu saat pembuatan dan memudahkan pada saat panen. Mempertimbangkan hal-hal 
diatas tersebut pembuatan kolam lele dari gentong sangat efisien digunakan untuk dilakukan dirumah warga yang memiliki pekarangan rumah yang sempit.

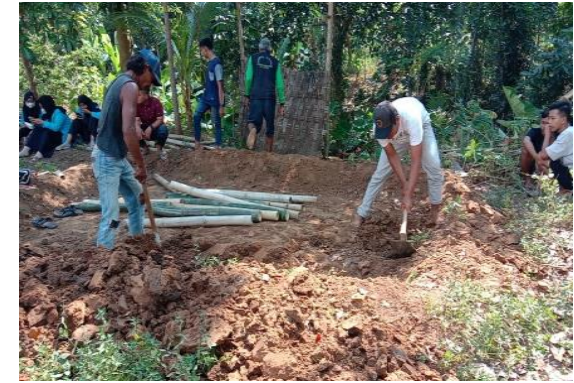

(a)

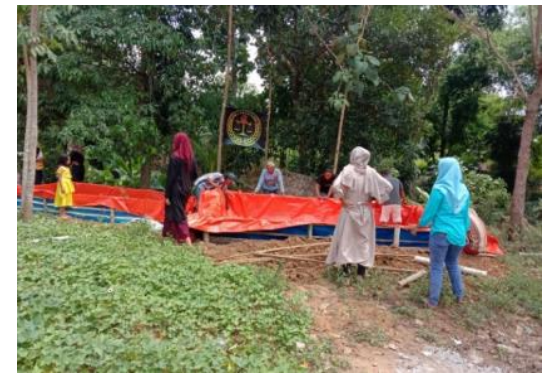

(b)

Gambar 2. Perluasan Kolam (a) Proses Pengalian (b) Pemasangan Terpal Untuk Perluasan Kolam Ikan Lele

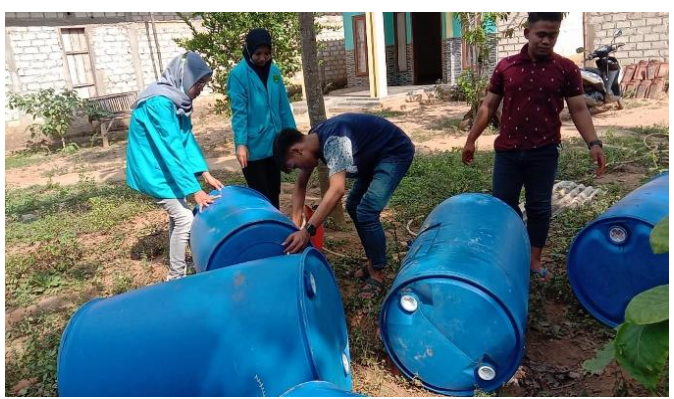

Gambar 3. Pembuatan Kolam Lele Dengan Gentong

Cara menggunakan gentong sebagai media atau pengganti kolam untuk memelihara lele diletakkan dalam posisi di baringkan. Posisi berbaring tersebut memberikan permukaan air yang lebih luas dibandingkan dengan posisi tegak. Gentong sebagai media untuk memelihara lele harus mengikuti kaidah umum dalam teknik budidaya lele yakni penebaran benih lele dilakukan untuk benih-benih yang umurnya sama satu dengan yang lain. Langkah ini dilakukan agar dalam gentong tidak terjadi kanibalisme di antara sesama lele yang hidup di dalamnya. Gentong memiliki ruang yang tidak begitu luas sehingga jumlah atau populasi benih yang dibesarkan dalam gentong tersebut dibatasi.

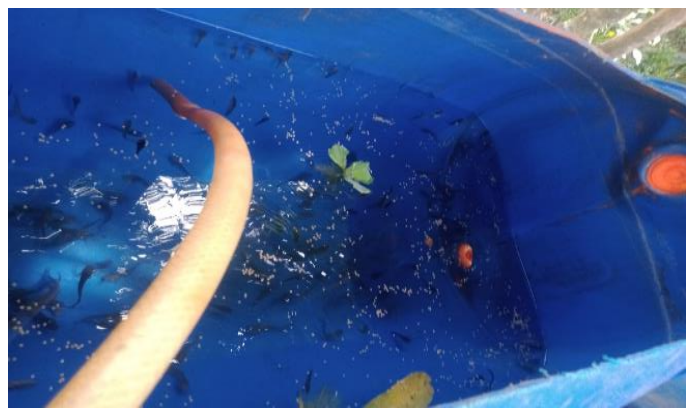

Gambar 4. Pembibitan Ikan Lele Dalam Gentong

Gentong yang digunakan sebanyak 5 buah untuk proses pembibitan dan ditambah 5 buah lagi pada saat untuk proses pembesaran. Kami menambahkan 1300 ekor bibit lele. Gentong yang digunakan memiliki ukuran sebesar 200 liter yang mampu menampung bibit lele sebanyak maksimal 200 ekor. Jika digunakan untuk pembesaran bisa diisi sesuai dengan ukuran lele.

Untuk proses pembersian kolam dilakukan 1 kali dalam seminggu pada kegiatan ini kami hanya mendampingi secara online melalui media WhatApp dan melakukan evaluasi tentang perkembangan ikan lele tersebut. 


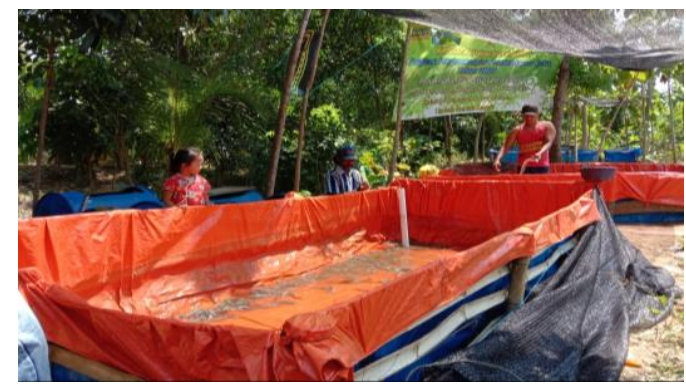

Gambar 5. Pengurasan Kolan Ikan Lele

\subsection{Perluasan kandang maggot}

Kegiatan selanjutnya adalah perluasan kandang maggot. Kadang manggot yang sebelumnya hanya berukuran $2 \times 1$ meter diperluas menjadi $2 \times 2$ meter. Kegiatan tersebut dilakukan oleh anggota karang taruna desa Sukowati dan didampingi oleh sebagian anggota secara langsung.

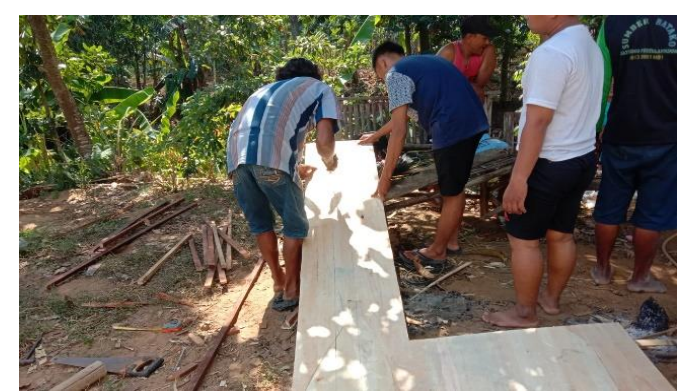

Gambar 6. Proses Perluasan Kandang Manggot

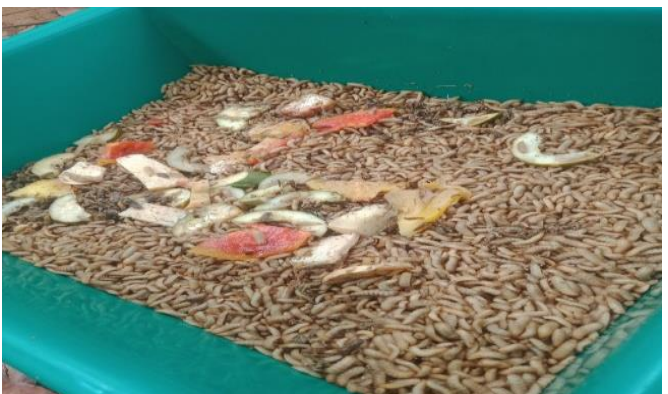

Gambar 7. Bibit Maggot

Selain itu ditambahkan juga bibit manggot sebanyak 5 kilogram. Ditambahkannya bibit ini untuk mengimbangi penambahan bibit lele agar tidak terjadi kekurangan pakan dan menekan biaya pakan untuk lele. Untuk proses pengawasan bibit manggot dilakukan secara online melalui media WhatApp yang dilakukan setiap hari. Selain itu dalam satu minggu sekali dilakukan pendampingan secara langsung oleh beberapa anggota tim.

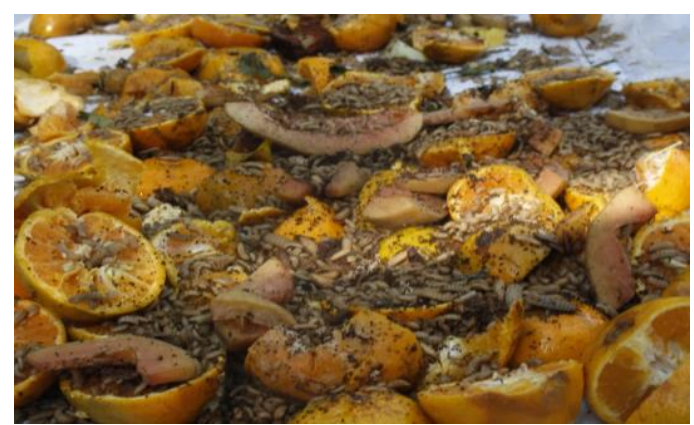

Gambar 8. Proses Pemberian Makan Manggot 
Pemberian makan untuk maggot dilakukan sehari sekali, untuk pakan maggotnya sendiri diberikan sampah organik dari rumah tangga. Sampah tersebut dikumpulkan dari kegiatan bank sampah yang dilakukan. Sehingga selain menekan biaya untuk pakan maggot dari hasil bank sampah bisa digunkan untuk pendapatan tambahan bagi warga, selain itu juga meminimalisir penumpukan sampah dan menjaga lingkungan tetap bersih.

\subsection{Inovasi Produk}

Setelah lele siap panen akan diolah menjaadi produk inovasi diantaranya abon lele, nugget lele dan kerupuk lele. Untuk kegiatan ini dilakukan oleh beberapa ibu-ibu PKK yang didampingi secara langsung oleh tim. Penambahan nugget didasarkan pada bentuk dari nugget yang dapat divariasikan dan dapat memperpanjang daya simpan dari khasiat yang dimiliki oleh ikan lele. Nugget dapat bertahan lama apabila disimpan dalam kondisi beku. Selain itu, pengolahan nugget mudah dilakukan dan juga bisa menjadi solusi untuk menyiasati anak yang kurang suka makan ikan lele.

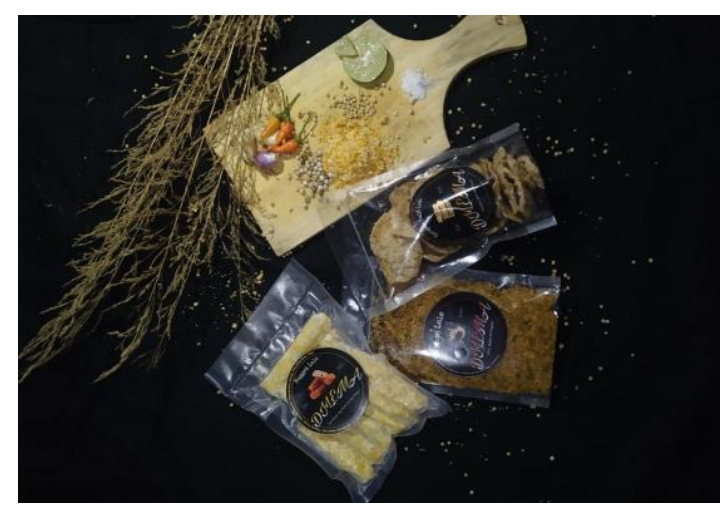

Gambar 9. Produk Inovasi

Selain penambahan nugget lele daging ikan lele juga diinovasikan menjadi krupuk lele. Kerupuk lele adalah salah satu kerupuk yang mengandung protein hewani yang tak kalah lezatnya dibanding kerupuk lain. Selain gurih dan bergizi tinggi, kerupuk lele dapat dimanfaatkan sebagai lauk, camilan, obat dan lain sebagainya.

Dengan demikian, kerupuk lele merupakan hasil produksi perikanan yang mempunyai andil besar dalam mengatasi masalah gizi masyarakat, karena kerupuk ikan lele sarat akan gizi yang diperlukan untuk kehidupan yang sehat. Zat-zat gizi yang ada pada kerupuk ikan lele sangat mudah dicerna dan dimanfaatkan oleh tubuh. Itulah sebabnya, maka ikan sangat dianjurkan untuk dikonsumsi anak-anak yang sedang dalam masa pertumbuhan, ibu hamil dan menyusui, orang yang sedang sakit atau dalam proses penyembuhan, serta usia lanjut. Pengolahan ikan lele menjadi beberapa produk diatas mempunyai tujuan utama untuk memperluas pasar dan menambah nilai jual ika lele tersebut.

\subsection{Pendampingan Pemasaran}

Selanjutnya kami melakukan pendampingan mengenai pemesaran produk yang akan dilakukan secara online. Pemasaran yang akan dilakukan ada beberapa cara. Yang pertama kami akan memasarkan produk kami dengan cara dititipkan toko-toko yang sudah menjalin kerja sama dengan kami. Tetapi dikarnakan kegiatan ini dilakukan pada masa pandemi COVID-19 dan masih diberlakukannya PPKM cara tersebut kurang efektif. Oleh karna itu kami lebih mengencarkan pemasaran secara online. Pemasaran ini melalui sosian media seperti instagram, story whatapps dan facebook. Selain itu juga kami pasarkan melalui marketplace seperti shopee. Dengan ini diharapkan bisa menambah penjualan karna jangkauan pasar yang semakin luas. 


\section{KESIMPULAN}

Setelah dilakukannya program pendampingan dan pemberdayaan desa Pemanfaatan Budidaya Lele Dan Maggot Sebagai Pengembangan Alternatif Bisnis Industri Rumahan Dan Pengolahan Limbah Rumah Tangga Di Desa Sukowati Kecamatan Kapas Kabupaten Bojonegoro dapat disimpulkan bahwa perluasana kolam degan ditambahkan nya 10 gentong dan pembesaran kandang maggot dari $2 \times 1$ meter menjadi $2 \times 2$ meter. Pendapatan masyarakat di desa tersebut dapat bertambah dengan menjual ikan lele segar dan produk inovasi baru meskipun pada saat diberlakukannya kebijakan PPKM pada masa pandemi COVID-19. Pengetahuan dan keterampilan masyarakat tentang pengolahan ikan lele mulai dari pembimbitan sampai dengan pemasaran produknya juga bertambah baik. Yang pada awalnya hanya di olah menjadi abon lele sekarang bisa manjadi nugget dan kerupuk lele. Pengadaan bank sampah membantu penggolahan sampah organik yang berasal dari limbah rumah tangga sebagai pakan manggot membantu mengatasi sebagian masalah sampah dalam lingkungan setempat. Sehingga lingkungan sekitar semakin bersih dan mengurangi biaya untuk pakan lele menggunakan manggot sebagai pakan tambahan.

Untuk kedepannya diharapkan pemerintah dan masyarakat desa sukowati bisa bekerjasama dengan baik sehingga kegiatan ini masih bisa berlangsung tanpa hambatan. Sehingga dari program P3D ini bisa menjadi pendapatan tambahan bagi masyarakat desa sukowati dan bisa membantu masyarakat dalam menghadapi masa pandemi COVID-19.

\section{UCAPAN TERIMA KASIH}

Penulis mengucapkan terima kasih kepada dikti yang telah memberi dukungan financial terhadap pengabdian ini.

\section{DAFTAR PUSTAKA}

Fitriani, F.,Imaniska, U., Lastari Faustiar, I., \& Mudjihartik, E.,(2019).Pelatihan Pengolahan Nugget Lele Bagi Masyarakat Desa Gelang Sidoarjo. Abadimas Adi Buana.03(1).17-20. http://jurnal.unipasby.ac.id/index.php/abadimas/article/view/1922

Mudeng. N., Mokolensang,F., Kalesaran,O., Pangkey,H., \& Lantu,S., (2018). Budidaya Maggot (Hermetia Illuens) Dengan Menggunakan Beberapa Media (Cultvation Of Maggot (Hermetia Illuens) Using Several Different Media).Budidaya Perairan September 2018. 6 (3): 1 - 6. https://ejournal.unsrat.ac.id/index.php/bdp/article/view/21543/0

Purnomo B., \&. Putri J,. (2020). Analisis Usaha Pembesaran Lele Dengan Menggunakan Pakan Tambahan Maggot Black Soldier Fly (Bsf) Di Upr Christanto Darmawan Yogyakarta Business Analysis Of Catfish Enlargement Using Black Soldier Fly (Bsf) Maggot As Additional Feed In Upr Christanto Darmawan Yogyakarta .Jurnal Chanos Chanos.18 (1). 19-27. http://ejournalbalitbang.kkp.go.id/index.php/chanos2/article/view/8985

Prasetyo , B.,(2021). Efektivitas Penggunaan Maggot Segar (Hermetia Illucens) Pada Ransum Terhadap Pertumbuhan Ikan Lele. In Program Studi Pendidikan Biologi Fakultas Tarbiyah Dan Keguruan. Universitas Islam Negeri Raden Intan, Lampung.

Salman. Ukhrowi,M., \& Azim,T.,(2020). Budidaya Maggot Lalat Bsf Sebagai Pakan Ternak .J.K P. (Junal Karya Pengabdian).2(1).1-6. https://jkp.unram.ac.id/index.php/JKP/article/view/34

Sukirno,S.,(2011).Makroekonomi teori pengantar. 3, PT RajaGrafindo, Jakarta.

Suwandi,. Sudargo. \&, Sukma A., (20170). Upaya Peningkatan Penghasilan Tambahan Warga Anggota Kelompok Posdaya Melalui Budidaya Ikan Lele Di Pekarangan Rumah. J-Abdipamas (Jurnal Pengabdian Kepada Masyarakat). 1 (1), 66-75. https://ejurnal.ikippgribojonegoro.ac.id/index.php/J-ABDIPAMAS/article/view/83/72

Widiasih, W., Muhimatul K., Febri S., H. Prasetyo, A., \& Eka P,. (2020). Pkm Budidaya Lele Sebagai Alternatif Mata Pencaharian Petani Sawah Tadah Hujan Di Desa Jukong.Abadimas Adi Buana. 3 (2):59-66. http://jurnal.unipasby.ac.id/index.php/abadimas/article/view/2173 